of the Order and, above all, without even giving the declarant state a hearing. Amplification of the rationale would also have been commendable in view of the novelty of the legal issues involved and in order to refute the extreme interpretations of the concept of "intervention as of right" that seem to continue to live in certain opinions of international jurists. The circumstances surrounding the Court's decision might reinforce the suspicions-noticeable in other aspects of the Nicaragua case-of politicization of judicial proceedings and anti-Western bias. ${ }^{131}$ All this is unfortunate.

The main legal issue, however, the admissibility of intervention under Article 63 in the phase of proceedings on preliminary objections (possibly including the question of certain limitations in this respect), remains open. In the words of Judge Oda:

Had El Salvador's initial Declaration been properly formulated, had Nicaragua's observations been properly interpreted, and had the procedures of the Court been properly pursued, El Salvador's Declaration might well have been the first case of intervention under Article 63 of the Statute to be considered by the Court at a jurisdictional phase of a case. ${ }^{132}$

JERZY SZTUCKI*

\title{
In Memoriam: Professor Ted L. Stein (1952-1985)
}

Ted L. Stein, a leading contributor to this Journal, died on June 12, 1985. His untimely death in a fishing accident cut short the career of one of the most promising young scholars in our profession. Despite his youth, he had a long and productive involvement in international law. He was a 1974 graduate of the Woodrow Wilson School of Public and International Affairs at Princeton University and a 1977 graduate of the Harvard Law School. At Harvard he was Articles Editor of the Harvard International Law Journal. After clerking for the Honorable Irving $L$. Goldberg of the Fifth Circuit Court of Appeals, he served as an attorney in the State Department's Office of the Legal Adviser. While in that office, he played an important role in shaping the U.S. arguments in the Iranian Hostages case. In 1980 he joined the law faculty of the University of Washington where he was recently approved for promotion to the rank of professor. In the fall of 1983, he visited at the University of Michigan School of Law. This past spring, he was elected to the Executive Council of the American Society of International Law.

During the course of his 5 short years in academia, he produced scholarship that catapulted him into the front ranks of the field. He published two articles

\footnotetext{
${ }^{131}$ On this aspect of the Nicaragua case, see the Editorial Comment by Thomas M. Franck, Icy Day at the ICJ, 79 AJIL 379 (1985); see also Observations by the U.S. Department of State on the ICJ's Nov. 26, 1984 Judgment, $i d$. at 423.

1321984 ICJ REP. at 221.

* Professor of International Law, University of Uppsala.
} 
in this Journal, Contempt, Crisis, and the Court: The World Court and the Hostage Rescue Attempt (76 AJIL 499 (1982)), and Jurisprudence and Jurists' Prudence: The Iranian-Forum Clause Decisions of the Iran-U.S. Claims Tribunal (78 AJIL 1 (1984)). The former earned him the 1983 Francis Deák Prize from the ASIL for the best scholarship published in the Journal in the previous year by a young author. As an active member of the ASIL, he appeared twice on the program of the Annual Meeting. He spoke in 1982 on the "ICJ Decision in the Libya-Tunisia Continental Shelf Case" (76 ASIL Proc. 161 (1982)), and in 1984 on the "Decisions of the U.S.-Iran Claims Tribunal."

His well-written and argued scholarship documents his deep understanding of, and dedication to, international law. All four of these pieces focus on international dispute settlement tribunals. They evince a sophisticated appreciation of the role such tribunals play in the international legal system. At the time of his death, he had a paper pending publication in the Harvard International Law Journal, and he was working on a book with Professor William T. Burke of the University of Washington. Had he lived to pursue his scholarship further, his contributions to the field of international law would have been enormous.

In addition to his devotion to scholarship, Ted Stein took a strong interest in his colleagues and students. He was known as an excellent teacher at Washington and played a leadership role at that law school. At the same time, he was a kind and gentle person who was liked by all. In his memory there has been established at the University of Washington School of Law the Ted L. Stein Memorial Fund.

Those of us who knew him well found him to be a most valuable person with whom to discuss matters of international law. His mastery of the field and his eagerness to "brainstorm" with others made him a special colleague. It is difficult to comprehend the extent of the loss suffered by his early and tragic death.

Jonathan I. ChaRney*

\section{CORRESPONDENCE}

The American Journal of International Law welcomes short communications from its readers. It reserves the right to determine which letters should be published and to edit any letters printed.

TO THE EDITOR IN CHIEF:

June 17,1985

In Progressive Development of International Law and the Package Deal (at p. 871 supra), Hugo Caminos and Michael R. Molitor quite accurately portray the procedural underpinnings of the negotiations at the Third United Nations Law of the Sea Conference (UNCLOS III) as involving a "package

* Professor of Law, Vanderbilt University. 